\title{
Damage and recovery in intertidal Fucus gardneri assemblages following the ‘Exxon Valdez' oil spill
}

\author{
Andrew P. De Vogelaere, Michael S. Foster \\ Moss Landing Marine Laboratories, PO Box 450, Moss Landing, California 95039, USA
}

\begin{abstract}
In March 1989, the 'Exxon Valdez' spilled over 10 million gallons (ca 38 million 1) of crude oil into Prince William Sound, Alaska, USA. The spill was followed by massive clean-up using hot seawater at high pressure as well as other mechanical and chemical techniques. We studied initial damage and subsequent recovery in the upper margin of the Fucus gardneri assemblage on protected shores by comparing sites that were unoiled, oiled and cleaned with hot water at high pressure, and oiled but less intensely cleaned. F. gardneri cover averaged $80 \%$ on unoiled sites but $<1 \%$ on all oiled and cleaned sites 18 mo after the spill. The abundances of barnacles, littorine snails and limpets varied among sites and species, and this variation was associated in part with differences in their life histories. F gardneri cover was still extremely low on oiled and cleaned sites $2.5 \mathrm{y}$ after the spill. Holdfasts that persisted after cleaning did not resprout. F. gardneri recruitment was lowest at intensely cleaned sites, and most recruits occurred in cracks near adults. Recruits were less abundant under adult canopies but placing canopies over recruits did not decrease their survivorship over 5 mo. Natural weathering of tar was rapid, with most marked patches gone in less than 1 yr. We conclude that intense mechanical cleaning following this oil spill increased damage and slowed recovery. Such methods should be avoided if reduction of environmental damage is the primary objective of post-spill management decisions. The recovery of $F$ gardneri at its upper margin might be enhanced by devices that retain moisture and increase substratum rugosity.
\end{abstract}

KEY WORDS: Cleaning · Damage ·'Exxon Valdez' Fucus gardneri - Oil spill · Prince William Sound Recovery $\cdot$ Recruitment $\cdot$ Restoration

\section{INTRODUCTION}

Oil spills may cause large-scale disturbances on temperate rocky shores, but it is difficult to generalize about the amount of damage because spills vary greatly in amount, chemical composition, and degree of weathering before reaching the shore (Foster et al. 1988, Coles \& Gunay 1989, Mielke 1990). Species and environments (e.g. giant kelp versus surf grass, exposed versus protected shores) are also affected differently by oil (Baker 1976, Cairns \& Buikema 1981, Straughan 1983, Stacey \& Marcotte 1987, Foster et al. 1988). A better understanding of the biological effects of individual spills is still necessary to make predictions about the effects of future spills (Mann \& Clark 1978, National Research Council 1985, Foster et al. 1990).
Clean-up efforts inevitably follow large oil spills, often directed more by social and political pressure than by concern for environmental damage (Siva 1979, Foster et al. 1990). Mechanical removal and bioremediation were used extensively to clean up the over 10 million gallons (ca 38 million l) of crude oil spilled in March 1989 by the tanker 'Exxon Valdez' in Prince William Sound, Alaska, USA (Marshall 1989, Foster et al. 1990, Michel 1990, 1991, Stone 1992). Mechanical cleaning included wiping rocks with absorbent material, picking up debris, and flushing the shore with seawater at a range of pressures [low to $>100$ psi (6.89 bar)] and temperatures (ambient to $60^{\circ} \mathrm{C}$ ). Bioremediation consisted of applying fertilizers to presumably enhance oil degradation by bacteria. Although it is commonly assumed that clean-up reduces damage 
and increases recovery rates, information is scant and largely anecdotal (Siva 1979, Foster et al. 1990, Houghton et al. 1992)

Before rocky-shore assemblages are able to recover naturally, the remaining oil, often in the form of tar, must be removed from the substratum. Tar may degrade by natural processes (e.g. photochemical reactions, ice scour, dissolution) or be removed by clean-up efforts, with the effects of the latter on surrounding surviving organisms largely unknown (see above). Weathering rates of tar vary with wave exposure and temperature (Mielke 1990. Strand et al. 1992) but, again, this information is based largely on anecdotal observations. Understanding weathering rates of tar on rocky shores would greatly improve the ability to make sound decisions about clean-up operations.

Fucus gardneri Silva forms extensive, nearly pure stands that cover thousands of kilometers of coastline in Prince William Sound and provides habitat and/or food for many barnacles, limpets and littorine snails (pers. obs.). This assemblage was heavily oiled at many sites following the 'Exxon Valdez' oil spill and was subjected to a major clean-up effort (Foster et al. 1990).

The effects of oil on Fucus spp. and ather intertidal Fucales have been widely noted (reviews in O'Brien \& Dixon 1976, National Research Council 1985, Foster et al. 1988) because these plants are common and conspicuous members of the flora on many temperate shores. Of particular relevance to the present study, however, are the processes affecting recruitment of fucoid algae into areas where they have been completely removed. Dispersal (via zygotes or embryos) is probably limited to meters or less around adult plants (Sousa 1984, Brawley \& Johnson 1991). However, receptacles at the tips of Fucus blades can fill with air and if such plants are fertile and detach from the substratum they could disperse propagules over large distances. This possibility has not been examined. Early survivorship of recruits is negatively affected by grazers (Southward \& Southward 1978, Lubchenco 1983, Hawkins \& Southward 1992), wave action (Vadas et al. 1990), overstory canopies (Brawley \& Johnson 1991, McCook \& Chapman 1991) and osmotic and temperature stresses during low tides (Wright \& Reed 1990, Brawley \& Johnson 1991).

Fucus spp. populations can recover rapidly (ca 1 yr) after nearly complete removal (Lubchenco 1983, McCook \& Chapman 1991). Hawkins \& Southward (1992) found that recovery was facilitated by the reduction in grazers after the 'Torrey Canyon' oil spill and clean-up. and Lubchenco (1983) showed that Fucus vesiculosus colonization was enhanced by microtopographic relief that provided a refuge from grazing. Fucus spp. recovery can also be enhanced in some species by vegetative regeneration from holdfast tissue (McCook \&
Chapman 1992) and perhaps from 'germling banks' that could function like seed banks in flowering plants (Ang 1991).

Most studies of fucoid recruitment and recovery, however, have been done in the center of the vertical distribution of populations. These results may not apply to recovery after oiling and clean-up at the upper margin of distribution where plants are growing near their physiological limits (Coleman 1933, Schonbeck \& Norton 1978). Conditions necessary for successful recruitment in this upper margin may occur very infrequently, and growth may be slow relative to populations in more favorable environments lower on the shore (Foster 1982, Underwood \& Jernakoff 1984, Foster et. al. 1988). Favorable conditions for recruitment may be even less likely in intensely cleaned areas because shaded, moist microhabitats provided by adult plants (Dayton 1975) can be eliminated. While adults may inhibit recruitment lower on the shore (discussed above), they may enhance it at the upper margins where conditions are more stressful. Moreover, intense cleaning with hot water may kill plants that are not washed off the rocks, eliminating possible regrowth from remaining fragments.

In this study we examined the effects of the 'Exxon Valdez' oil spill and subsequent cleam-up on high intertidal Fucus gardneri populations and associated organisms. The abundance of all macroorganisms was assessed 18 mo after the spill, and longer term monitoring of F. gardneri was done in areas cleaned at different intensities. We also investigated processes affecting $F$. gardneri recruitment, early survivorship and vegetative regeneration, and we determined natural weathering rates of tar.

\section{METHODS}

Study area and site selection. The study was done in Herring Bay, Prince William Sound, Alaska $\left(60^{\circ} 2^{\prime} \mathrm{N}\right.$, $\left.145^{\circ} 50^{\prime} \mathrm{W}\right)$, a very wave-protected area with tree branches reaching just above mean higher high water (MHHW) and large macroalgae growing attached to small stones. Large, continuous bands of Fucus gardneri ring the Bay on rock benches and gravel beaches at the highest through mid intertidal levels. Our studies focused on rock benches at the upper margin of F gardneri distribution, just below the black lichen Verrucaria zone at 2.1 to $2.7 \mathrm{~m}$ above MLLW. This region generally receives the greatest amount of oil and most intense clean-up (Foster et al. 1988, 1990), and logistic constraints at this remote area limited access to lower intertidal regions.

Selecting sites that received different cleaning intensities was difficult. The Alaska Department of Environ- 
mental Conservation maintained records of clean-up methods used and degree of oiling for segments of shoreline throughout the impacted area (ADEC 1989, 1990). Unfortunately, the oiled segments could be hundreds of meters long, and subsections within them that received different cleaning intensities were not distinguished. Moreover, some of the shoreline clean-up history was clearly incorrect (e.g. purported intensely cleaned sites were found containing dense Fucus gardneri beds). We therefore devised our own categories and criteria for sites based on 3 general cleaning intensities, and observations made in September 1990, 18 mo after the spill and onset of clean-up:

(1) Control sites: known not to be oiled or cleaned.

(2) Less intensely cleaned sites: locations with a distinct oil band where the highest intertidal and terrestrial zones met, and a mid intertidal zone of adult Fucus gardneri that was more dense than in (3).

(3) Intensely cleaned sites: locations with no distinct continuous oil band, and a mid intertidal zone consisting mostly of Fucus gardneri holdfast remnants and a few mature plants.

Our rationale for these criteria was that a continuous oil band would not persist through intense cleaning. Since the upper margin of the Fucus gardneri zone (our primary area of study) was essentially bare, the condition of adjacent zones was used as evidence for intensity of cleaning.

Available ADEC shoreline assessments, based on observations by field supervisors and independent observers, indicated that our 'intensely cleaned' category generally received higher pressure and warmer water cleaning than our 'less intensely cleaned' category (ADEC 1990). Site selection was also aided by personnel involved in shoreline/clean-up assessment in 1989. The sites all had similar wave and wind exposure.

The optimal design would have had a greater range of cleaning intensities, randomly assigned cleaning treatments, and an oiled, not-cleaned treatment. The opportunity for such a design was lost during the initial planning stages of the oil spill response. We attempted to compensate for the problem of confounding treatment effects and intrinsic differences among sites in natural 'experiments' (Hurlbert 1984) by selecting sites based on evidence from zones above and below the study areas (confirmed by cleaning records), interspersing treatments, and replicating on separate islets separated by at least $100 \mathrm{~m}$. Moreover, the Fucus gardneri zone in Prince William Sound is exceptionally uniform over thousands of kilometers (pers. obs.).

Surveys of initial damage. In September 1990, sampling was done in 2 replicate sites of each cleaning intensity category. A $20 \mathrm{~m}$ long measuring tape was laid parallel to the shore across each study site within the 2.1 to $2.7 \mathrm{~m}$ tidal range in the high Fucus gardneri zone. Tidal height was found using a stadium rod, line level and tide charts. Five $50 \times 50 \mathrm{~cm}$ quadrats were placed randomly along each tape. In each quadrat, percent cover was estimated by identifying species that came in contact with a pin lowered at 16 points delimited by a grid of evenly spaced lines in the quadrat. Grazers and individual F. gardneri recruits were also counted and the quadrat was photographed.

Differences in abundance of individual species between cleaning treatments were tested with ANOVA, with sites nested within treatments. Replicate sites within treatments were pooled in figures when no statistically significant difference was found between sites. Homogeneity of variances was tested with Cochran's test and the data transformed (arcsin on $\%$ cover, square root on counts) and retested when necessary before performing the ANOVAs. Other analyses are described in the 'Results'.

Recovery of Fucus gardneri and weathering of tar. F. gardneri recovery was monitored in September 1990, and in April, June and August 1991. Percent cover of $F$ gardneri was measured on each date at all 6 of the treatment sites described above. Photo or point quadrats (sensu Foster et al. 1991) were used to estimate cover depending on time available in the field and there were no significant differences between techniques, probably because $F$. gardneri was the overstory ( $t$-tests, $0.62<\mathrm{p}<0.96$ ). Differences were determined by comparing cover sampled with both techniques in 10 quadrats in each of the 3 treatment types. The differences between the estimates of mean cover were $<3 \%$. A total of $14 \mathrm{~F}$. gardneri holdfast remains from the cleaning process were repeatedly photographed to detect signs of regrowth. They were relocated by triangulation from benchmarks and plastic tags epoxied on adjacent substratum. Finally, in June 1991, the density of F gardneri recruits (plants $<2.5 \mathrm{~cm}$ ) was sampled in $10 \times 10 \mathrm{~cm}$ randomly positioned quadrats, and mid and high zone $F$ gardneri cover was compared using the above methods and sites.

Weathering rates of tar were measured for 10 haphazardly selected tar patches at an intensely cleaned site and 12 patches at each of 2 less intensely cleaned sites. Tar patches were permanently marked in September 1990 (as for holdfasts above) and changes in their area determined from successive photographic slides.

The $50 \times 50 \mathrm{~cm}$ quadrats sampled in September 1990 were also used to determine substrata (barnacles, tar, smooth rock, cracks) associated with successful Fucus gardneri recruitment. The cover of barnacles and tar was estimated in the initial damage survey described above. The cover of smooth rock and cracks was visually estimated by counting the number of 25 equal sub- 
divisions of the quadrat that were dominated by either category. The type of substratum beneath the $10 \mathrm{~F}$ gardneri recruits closest to the upper left corner of each quadrat was determined. We assumed that this subsample of F. gardneri was representative of the entire quadrat. The presence or absence of $F$. gardneri adults within $1 \mathrm{~m}$ of the quadrat was also noted.

The relationship between number of recruits and the presence of adult canopies was examined in April and June 1991. In April, the upper margin of the Fucus gardneri zone at an unoiled site was stratified into patches with or without adult canopies, and the number of recruits were counted in 10 haphazardly located $10 \times 10 \mathrm{~cm}$ quadrats in each stratum. Similar sampling was done in June at 5 sites, 2 not oiled/not cleaned, 1 oiled/less intensely cleaned and 2 oiled/intensely cleaned. Stratification was as in April, but only 5 random quadrats were sampled in each stratum.

To evaluate the effects of adult canopy on recruitment and survivorship, canopy cover was altered in plots at an unoiled site in April 1991. Twelve $10 \times 10 \mathrm{~cm}$ plots at the upper margin of the Fucus gardneri zone were selected that had no adult $F$. gardneri canopy but contained more than 10 recruits. The corners of each plot were marked with epoxy and a numbered tag. Recruits were removed with tweezers until only 10 small plants $(<2.5 \mathrm{~cm})$ remained. The location of these plants was determined by triangulation from the corner markers. Small stones with attached adult F. gardneri were epoxied to the substratum around 8 plots to create treatments of $100 \%$ or 30 to $50 \%$ canopy. The 4 replicates of each treatment were allocated to the plots at random. Survivorship of the original recruits plus any new recruitment was determined in June and August 1991.
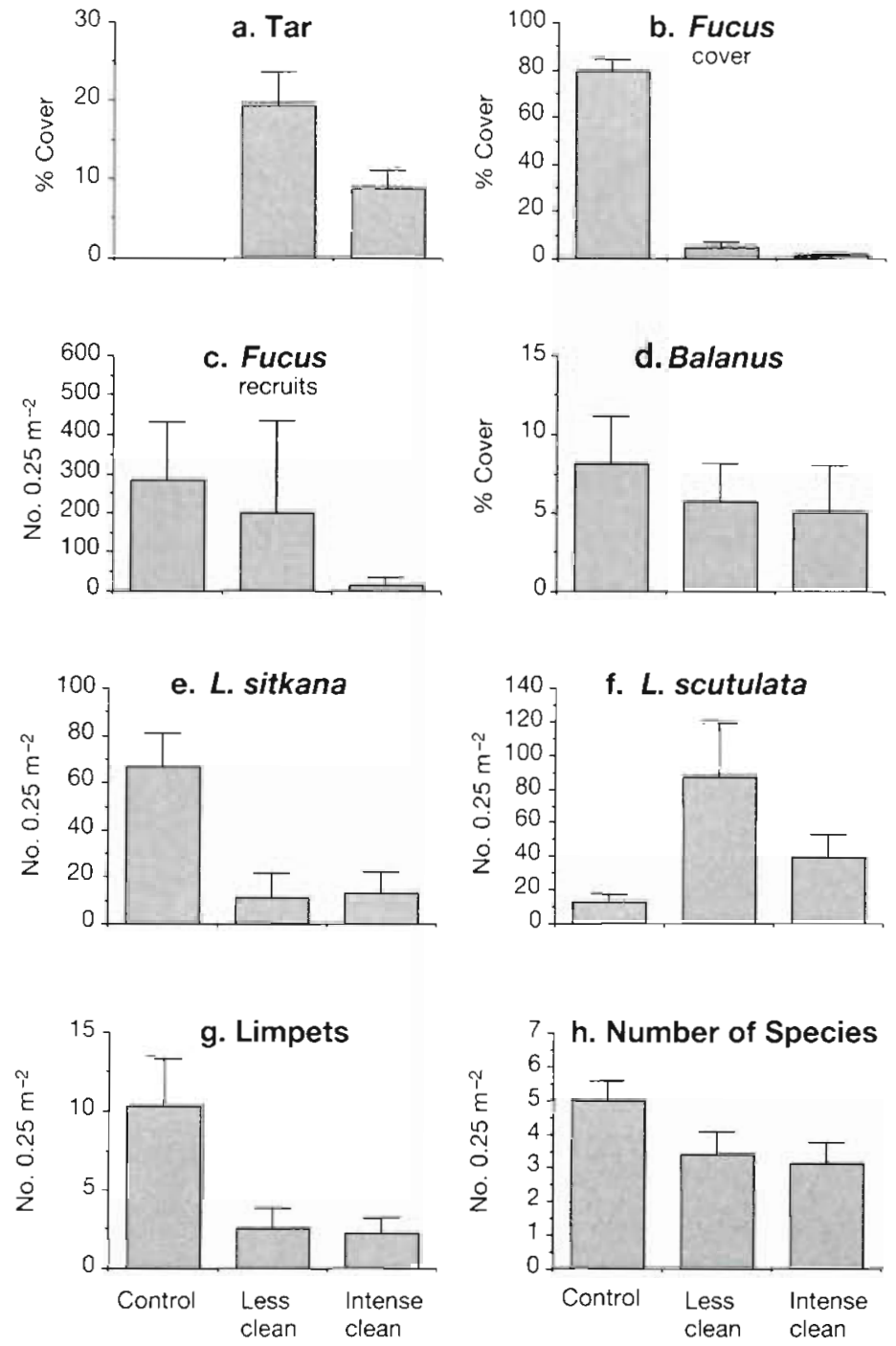

Fig. 1. Relationship between cleaning intensity and (a) \% cover tar, (b) \% cover of Fucus gardneri, (c) no. of F gardneri recruits, (d) \% cover of Balanus glandula, (e) no. of Littorina sitkana, (f) no. of L. scutulata, $(g)$ no. of limpets and $(\mathrm{h})$ no. of species. Abundances are means + SE from September 1990. n = 10 except for L. sitkana and F. gardneri recruits where $\mathrm{n}=2$ because site differences (Table 1) made pooling inappropriate

\section{RESULTS}

\section{Initial damage}

Fucus gardneri abundance was greatly reduced in oiled and cleaned sites, but the abundance of other common high intertidal species was more variable (Fig. 1, Table 1). Intensely cleaned sites had less tar on the shore, and no oil was found at the control sites (Fig. 1a). The percent cover of F. gardneri was much greater in the controls than in the cleaned sites (Fig. 1b) i the controls had large canopies characteristic of mature stands.
There was no significant difference in the cover of $F$. gardneri between the 2 iniensities of cleaning (Table 1), but there tended to be more recruits in less intensely cleaned sites (Fig. 1c). There were no significant differences among treatments in density of $F$. gardneri recruits because of great variability among sites (Table 1). There were no significant differences in Balanus glandula among sites 18 mo after the spill (Fig. 1d, Table 1). Littorina sitkana and limpets tended to be more abundant in the control sites (Fig. 1e, g) and Littorina scutulata tended to be more abundant in oiled and cleaned sites (Fig. 1f), but differences were not significant. 
Table 1. Effects of cleaning intensity and site on tar and species abundances in September 1990 (nested ANOVA). SNK multiple comparison tests on \% Fucus gardneri found in control sites were significantly different from both less intensely and intensely cleaned sites (ns: not statistically significant at $\alpha=0.05$ )

\begin{tabular}{|c|c|c|c|c|}
\hline & \multicolumn{2}{|c|}{$\begin{array}{c}\text { Treatment } \\
\text { effect }(\mathrm{df}=2)\end{array}$} & \multicolumn{2}{|c|}{$\begin{array}{l}\text { Replicate site } \\
\text { effect ( } \mathrm{df}=3 \text { ) }\end{array}$} \\
\hline & $F$ & $\mathrm{p}$ & $F$ & $\mathrm{p}$ \\
\hline$\% \operatorname{Tar}$ & 6.5 & ns & 3.4 & ns \\
\hline$\%$ Fucus gardneri & 70.8 & $\ll 0.01$ & 1.5 & ns \\
\hline No. of F. gardneri recruits & 1.2 & ns & 4.0 & $<0.05$ \\
\hline$\%$ Balanus glandula & 0.2 & ns & 2.1 & ns \\
\hline No. of Littorina sitkana & 3.9 & ns & 6.3 & $\ll 0.01$ \\
\hline No. of L. scutulata & 5.1 & ns & 1.78 & ns \\
\hline No. of limpets & 2.26 & ns & 2.59 & ns \\
\hline No. of species & 1.66 & ns & 1.75 & ns \\
\hline
\end{tabular}

In addition to the species above, other barnacles (Chthamalus spp.), mussels (Mytilus edulis), limpets (Tectura persona, Lottia pelta), crabs (Pagurus sp.), amphipods and plants (Neorhodomela aculeata, Gloeopeltis sp., Leathesia sp., unidentified lichens, and brown and red algal crusts) were also found, but none of their abundances exceeded $2.5 \%$ cover or $37.6 \mathrm{~m}^{-2}$. Species richness was not significantly different between control and oiled sites (Fig. 1h, Table 1).

\section{Recovery of Fucus gardneri}

Recovery of high intertidal Fucus gardneri beds at all disturbed sites was minimal during the study period. F. gardneri cover was $<1 \%$ at cleaned sites 29 mo after the spill (Fig. 2, Table 2). There was little difference in

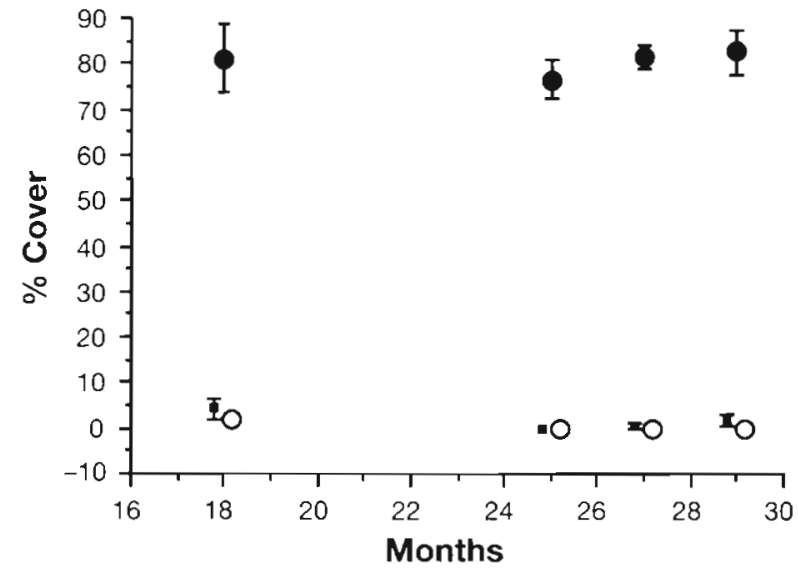

Fig. 2. Fucus gardneri. Mean percent cover ( \pm SE) vs time after oil spill in high intertidal sites that received different cleaning intensities. Zero percent cover is elevated on the $y$-axis for clarity. Some SEs are too small to be visible. (O) control ( $^{-}$) less intensely cleaned; $(O)$ intensely cleaned
Table 2. Fucus gardneri. Comparison of abundance $(\% \pm 1 \mathrm{SE}$, $\mathrm{n}=5$ ) in mid versus high intertidal zones in 3 cleaning treatments in June 1991 For logistical reasons, no data (nd) were collected at 1 mid intertidal, less intensely cleaned site

\begin{tabular}{|c|c|c|}
\hline & \multicolumn{2}{|c|}{$\%$ cover } \\
\hline & Site 1 & Site 2 \\
\hline \multicolumn{3}{|l|}{ Control } \\
\hline High & $83.8 \pm 3.3$ & $78.8 \pm 4.2$ \\
\hline Mid & $65.0 \pm 8.9$ & $91.4 \pm 3.7$ \\
\hline \multicolumn{3}{|c|}{ Less intensely cleaned } \\
\hline High & $0.0 \pm 0.0$ & $1.2 \pm 1.2$ \\
\hline $\mathrm{Mid}$ & $66.4 \pm 12.5$ & nd \\
\hline \multicolumn{3}{|c|}{ Intensely cleaned } \\
\hline High & $0.0 \pm 0.0$ & $0.0 \pm 0.0$ \\
\hline Mid & $2.6 \pm 2.6$ & $38.0 \pm 8.6$ \\
\hline
\end{tabular}

the cover of $F$. gardneri in the high intertidal zone among sites receiving different cleaning intensities (Table 2), but cover and the density of F. gardneri recruits were slightly higher at sites that received less intensive cleaning (Table 3). Percent cover of F. gardneri was greater in the mid intertidal than high intertidal zones at cleaned sites but, with the exception of the mid intertidal zone at less intensely cleaned site 1 , mid zone cover at cleaned sites was still much less than the cover in mid zones of control sites (Table 2). None of the 14 marked $F$. gardneri holdfasts that remained after cleaning survived and regrew.

\section{Weathering of tar}

Tar patches weathered rapidly by natural processes. During the first winter after marking, roughly $50 \%$ of the tar was removed (Fig. 3). After $11 \mathrm{mo}$, only $5 \%$ of the marked tar remained at one site. Variability in

Table 3. Fucus gardneri. Recruits (per $100 \mathrm{~cm}^{2}$ quadrat) found under and outside of canopies in June 1991 in areas subjected to varying cleaning intensity, mean ( $\mathrm{SE}), \mathrm{n}=5$. $\mathrm{p}$-values from

$t$-tests ${ }_{i}-$ : no data because no canopy was present at site

\begin{tabular}{|lccc|}
\hline Site & $\begin{array}{r}\text { Outside } \\
\text { canopy }\end{array}$ & $\begin{array}{c}\text { Under } \\
\text { canopy }\end{array}$ & $\begin{array}{c}\text { Significance } \\
(\mathrm{p})\end{array}$ \\
\hline Control & & & \\
1 & $28.8(8.4)$ & $1.8(1.8)$ & 0.04 \\
2 & $17.8(9.7)$ & $4.6(3.4)$ & 0.27 \\
Less intensely cleaned & & & \\
1 & $2.0(1.0)$ & - & \\
Intensely cleaned & & & \\
1 & 0 & - \\
2 & 0 & - \\
\hline
\end{tabular}




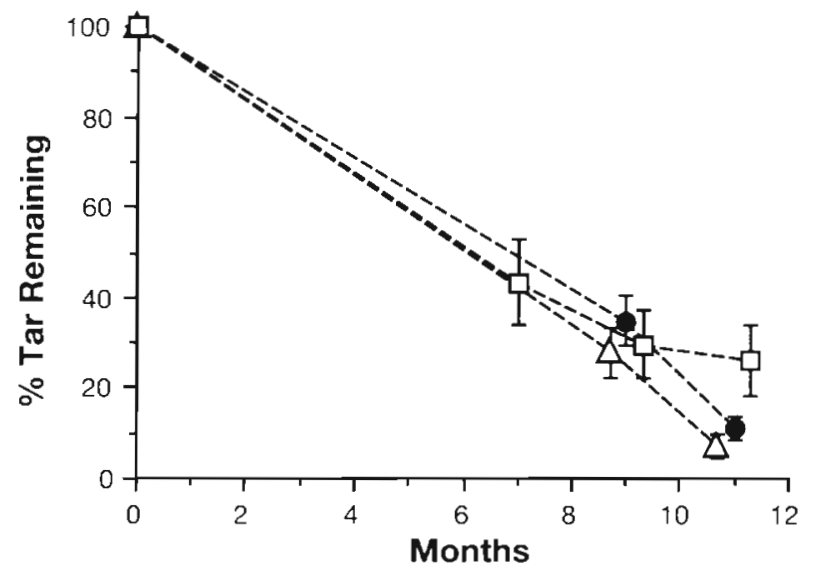

Fig. 3. Changes in size of tar patches (mean percent remaining $\pm \mathrm{SE}$ ) vs time. Original patch sizes were measured in September 1990 and ranged in area from 15 to $693 \mathrm{~cm}^{2}$. Different symbols represent different sites with 10 to 12 patches site ${ }^{-i}$

weathering rates within and among sites was low. No organisms settled on tar, but littorines were seen crawling across it.

\section{Recruitment of Fucus gardneri}

The vast majority of Fucus gardneri recruits were attached to rock in cracks (Fig. 4). The distribution of these recruits was significantly different from that expected based on the availability of the various substrata for settlement $\left(\chi^{2}=114.36, p \ll 0.001\right)$.

The number of recruits also varied depending on the proximity of adult plants and whether or not the substratum was under an adult canopy. Recruits were significantly more abundant when adult conspecifics were within $1 \mathrm{~m}$ of the quadrat (September 1990: $1360 \mathrm{~m}^{-2}, \mathrm{SE}=79, \mathrm{n}=13$ vs $128 \mathrm{~m}^{-2}, \mathrm{SE}=13$, $\mathrm{n}=17$; $t$-test, $\mathrm{p} \ll 0.01$ ). There were more small plants present outside of canopies than under them at an unoiled site in April 1991, but the difference was not significant (11.4 plants $100 \mathrm{~cm}^{-2}, \mathrm{SE}=4.7$ vs 4.1 plants $100 \mathrm{~cm}^{-2}, \mathrm{SE}=2.2, \mathrm{n}=10 ;$ t-test, $\mathrm{p}=0.2$ ).

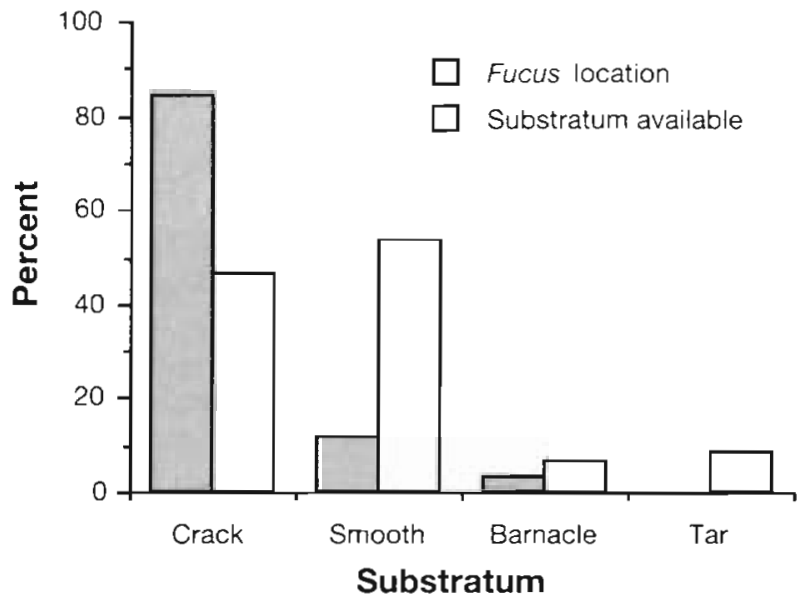

Fig. 4. Fucus gardneri. Distribution of recruits on various substrata. Data from all 6 sites and 30 quadrats combined

Two additional sites that were not cleaned were surveyed in June 1991 and had more recruits outside canopies than beneath them. Variation among quadrats was high, however, and the difference was significant at only 1 of the sites (Table 3). Surveys on the same date at less intensely and intensely cleaned sites found no recruits in the latter and only a few in the former (Table 3). This was $2 \mathrm{yr}$ after the oil spill and clean-up occurred. There were no adult plants in the upper margin at the intensely cleaned sites, and adults at the less intensely cleaned sites did not form a canopy over any quadrat.

Survivorship of small plants was high in the 3 canopy treatments over the 4 mo of observation of the canopy manipulation experiment, and all treatments had a net gain in recruits (Table 4). Although there was a trend of decreased survivorship in the no canopy treatment, none of the small differences on the 2 dates sampled were significant and there were no significant differences in numbers of new recruits. As suggested by the frequently large standard errors for the mean numbers of new recruits, recruitment was very patchy, ranging from 1 to 42 plants quadrat ${ }^{-1}$ in June, and 0 to 13 plants quadrat $^{-1}$ in August.

Table 4. Fucus gardneri. Results of natural overstory canopy manipulations on recruitment and survivorship. Experiment was begun in April 1991; data are means $(\mathrm{SE}), \mathrm{n}=4$. Treatment comparisons were made with a single factor ANOVA (df $=2$ ), with $F$-ratio and significance level ( $p$ ) given in the last row of each column. New recruits are cumulative from April

\begin{tabular}{|lcccc|}
\hline \multirow{2}{*}{ Treatment } & \multicolumn{2}{c}{ June 1991} & \multicolumn{2}{c|}{ August 1991} \\
& \% surviving & No. of new recruits & \% surviving & No. of new recruits \\
\hline $100 \%$ canopy & $97.5(2.5)$ & $12.5(9.9)$ & $85.0(6.5)$ & $18.5(12.3)$ \\
$30-50 \%$ canopy & $100(0.0)$ & $9.3(0.8)$ & $92.5(2.5)$ & $14.2(2.6)$ \\
No canopy & $85.0(8.7)$ & $3.3(0.6)$ & $72.5(13.8)$ & $10.7(2.5)$ \\
$F(p)$ & $2.4(0.15)$ & $0.6(0.57)$ & $1.3(0.32)$ & $0.3(0.76)$ \\
\hline
\end{tabular}




\section{DISCUSSION}

Upper shore Fucus gardneri populations were dramatically different among our site categories following the oil spill and clean-up and, for the reasons stated in 'Methods' above and discussed below, it is highly unlikely that these differences were present before the spill. Nearly all adult $F$. gardneri were killed, remnants did not resprout, there was a general lack of successful recruitment, and F. gardneri populations at their upper distributional limits were still essentially absent after 2.5 yr (Fig. 2). Heavily and moderately oiled sections of the shore in Herring Bay were mapped (ADEC 1989) and our observations indicated that these sections all received some cleaning. It was difficult to precisely determine cleaning history from ADEC records. However, assuming the oiled sections themselves were accurately mapped, then over $20 \mathrm{~km}$ or approximately $50 \%$ of the shore was affected. Total damage to $F$ gardneri and associated organisms was no doubt much greater than this as Herring Bay represents only a small part of the shoreline in Prince William Sound that was oiled and intensely cleaned.

A variety of information strongly indicates that clean-up, not the oil alone, caused most of the damage, although we could not rigorously determine this because sites were not available that had been oiled but not cleaned. We did find slightly higher Fucus gardneri cover and more recruits at less intensely cleaned sites. Moreover, Fucus does have some tolerance to crude oil (O'Brien \& Dixon 1976, National Research Council 1985) and plants that are damaged may be able to resprout (McCook \& Chapman 1992). In another area of Prince William Sound, Houghton et al. (1992) found that organisms that survived the oil spill did not persist after $2 \mathrm{~h}$ of experimental hot-water washing, and Foster et al. (1990) reported that organisms surviving the oil appeared to be destroyed by intensive cleaning. Houghton et al. (1992) also compared the abundance of organisms on both sides of borders apparently created when intense cleaning was abruptly halted within an area that was homogeneously oiled. Much more extensive damage was found on the intensely cleaned sides of the borders. Lees (1992) also concluded that damage was most severe in intensely cleaned sites. Our observations imply that the slow recovery of cleaned areas is probably related to the initial damage from cleaning; few survivors remained that might otherwise have provided habitat and propagules.

Oil degradation by natural processes was rapid (Fig. 3). It has been predicted that such weathering would be slow on wave-protected rocky shores (Sergy 1985, Foster et al. 1990, Mielke 1990). Michel (1990) suggested a potential for asphalt pavement to persist for decades on sheltered shores oiled during the 'Exxon Valdez' spill. Perhaps high rainfall and ice scour are as effective as high water motion in removing oil. The high weathering rate, combined with reduced damage by oil alone, indicate that much less intensive clean-up (e.g. skimming at high tide, vacuum pumping, use of absorbents) would have resulted in much less damage and faster recovery than cleaning with hot water at high pressure. Additional studies of petroleum weathering on shores in other locations are needed to more generally determine the effects of environmental differences on weathering rates.

The response of organisms associated with Fucus gardneri to oil and clean-up was variable among sites and species, but trends in their abundance may be related to life history characteristics and the lack of $F$. gardneri. Littorina sitkana was rare at all disturbed sites, probably because of its poor dispersal abilities. Adults of this species do not move far, lay eggs in gelatinous masses on the substratum, and do not disperse in the plankton (Ricketts et al. 1985). Moreover, the eggs and adults survive better in damp areas, as under F. gardneri canopies. While the results suggest that lack of $F$ gardneri canopy may have hindered $L$. sitkana recovery at cleaned sites, $L$. scutulata tended to be more abundant in areas without canopy (Fig. 1). L. scutulata disperses widely, as does Balanus glandula (Ricketts et al. 1985). It is therefore not surprising that there was a trend of higher abundance of these species at cleaned sites. We did not observe extensive blooms of ephemeral algae that often occur after oil spills (reviewed in Foster et al. 1988), perhaps because of grazing by L. scutulata.

Fucus gardneri recruitment was low at its upper margin (Table 2), and we could not sample long enough to determine the time to complete recovery. However, assuming oil and intense cleaning also removed most mid intertidal $F$. gardneri, the recovery rate in this region of the shore was comparable to that at other sites in temperate zones (Dayton 1971, O'Brien \& Dixon 1976, Lubchenco 1982, 1983, McCook \& Chapman 1991), and contrary to suggestions that recovery may be delayed at higher latitudes (National Research Council 1985, Mielke 1990). Our results indicate that differences in recovery may be greater at different vertical positions within the F. gardneri zone than between latitudes.

Several factors appeared to influence Fucus gardneri recruitment, but the mechanisms that created these recruitment patterns were less obvious. F. gardneri naturally recruited in greatest abundance in cracks (Fig. 4) and near adult conspecifics. Recruits were less abundant on smooth surfaces and under adult canopies, and none were found on tar. Manipulations 
of canopies over existing juvenile F. gardneri resulted in good survival and also some recruitment (Table 4), indicating that adult canopies were not sweeping juveniles off the rocks with a whiplash effect as described on wave-exposed coasts (Lewis 1964, Dayton 1971). Since recruits were less abundant under natural canopies (Table 3), the canopies may inhibit initial settlement or create a microhabitat (e.g. low light) that prevents early growth. It is also possible that recruitment in the canopy experiment may have been from the growth of very small juveniles that were present before the initial manipulation and not removed. Finally, the surprising results of high survival under canopies may indicate that, once a plant is established, increased moisture and shading is beneficial, particularly in the high intertidal zone. This provides a mechanism for our general observation that high intertidal F. gardneri was more dense in areas that received more freshwater runoff or had numerous cracks that retained moisture during low tide.

The upper Fucus gardneri zone in Herring Bay appears to be physiologically marginal for F. gardneri populations, and natural recovery may take decades. Since this habitat is also a source of primary production in the Sound and is the habitat most used by terrestrial fauna, restoration may be appropriate. The pattern of increased recruitment in areas that were moist, had cracks, and had local adults present suggests that laying degradable fiber nets with adult plants attached may be an effective restoration method. The adults would provide a source of propagules, and the nets would provide crevices and moisture (at low tide) next to the substratum. A simple irrigation system that would fill up at high tide and drain over the upper intertidal as the tide drops might also be used (e.g. absorbent material or troughs).

Despite the recognized damage and expense of clean-up operations, the option of not cleaning has not been tested seriously on rocky shores (Foster et al. 1990). Unfortunately, more rigorous determinations of the effects of clean-up are unavailable, and will perhaps remain so as long as economic, political, and legal considerations are primary in post-spill management decisions. Randomly assigned treatments of a range of cleaning intensities would be a simple and ideal design. We were unable to find heavily oiled sites in Herring Bay that received no or low-impact cleaning. Such sites must be incorporated as treatment types in future oil spill operations if questions concerning the effects of clean-up versus no clean-up are to be rigorously resolved. Nevertheless, our data and those from other spills reviewed in Foster et al. (1990) and Mielke (1990) indicate that intense cleaning of rocky shores following oil spills is not environmentally justified.
Acknowledgements. We gratefully acknowledge the generous assistance of the support team at the Camp David field station, especially the Jessen family and J. Nulph. G. Allison, S. Dearn, D. Jessen and D. Steller assisted with field work under arduous conditions. The local knowledge, insight and overall generosity of A. Hooten are particularly appreciated. C. Roberts carefully analyzed photographic slides and G. Hansen identified the difficult algae. Comments by R. Kvitek, A. J. Underwood, and anonymous reviewers helped clarify the manuscript. The study was funded by the U.S. EPA, with additional support from DB Consulting. We thank $\mathrm{H}$. Kibby for his help in initiating the project.

\section{LITERATURE CITED}

ADEC (Alaska Department of Environmental Conservation) (1989). Map: Herring Bay, Knight Is. five months maximum impact. $3 / 24 / 89$ to $8 / 24 / 89$. Map projection UTM, Zone 6. File: HER5MNTH. ADEC, Anchorage

ADEC (Alaska Department of Environmental Conservation) (1990). Daily shoreline assessment forms. Oil Spill Response Center. ADEC, Anchorage

Ang, P. O. Jr (1991). Natural dynamics of a Fucus distichus (Phaeophyceae, Fucales) population: reproduction and recruitment. Mar. Ecol. Prog. Ser. 78: 71-85

Baker, J. M. (1976). Marine ecology and oil pollution. John Wiley, New York

Brawley, S. H., Johnson, L. E. (1991). Survival of fucoid embryos in the intertidal zone depends upon developmental state and microhabitat. J. Phycol. 27: 179-186

Cairns, J., Buikema, A. L. (1981). Restoration of habitats impacted by oil spills. Butterworths, Boston

Coleman, J. (1933). The nature of intertidal zonation of plants and animals. J. mar. biol. Ass. U.K. 18: 435-476

Coles, S. L., Gunay, N. (1989). Tar pollution on Saudi Arabian Gulf beaches. Mar. Pollut. Bull. 20: 214-218

Dayton, P. K. (1971). Competition, disturbance and community organization: the provision and subsequent utilization of space in a rocky intertidal community. Ecol. Monogr. 41: 351-389

Dayton, P. K. (1975). Experimental evaluation of ecological dominance in a rocky intertidal community. Ecol. Monogr. 45: $137-159$

Foster, M. S. (1982). Factors controlling the intertidal zonation of Iridaea flaccida (Rhodophyta). J. Phycol 18: 285-294

Foster, M. S., De Vogelaere, A. P., Harrold, C., Pearse, J. S., Thum, A. B. (1988). Causes of spatial and temporal patterns in rocky intertidal communities of central and northern California. Mem. Calif. Acad. Sci. 9: 1-45

Foster, M. S., Tarpley, J. S., Dearn, S. L. (1990). To clean or not to clean: the rationale, methods, and consequences of removing oil from temperate shores. NW environ. J. 6: $105-120$

Foster, M. S., Harrold, C., Hardin, D. D. (1991). Point vs, photo quadrat estimates of the cover of sessile marine organisms. J. exp. mar. Biol. Ecol. 146: 193-203

Hawkins, S. J., Southward, A. J. (1992). The 'Torrey Canyon' oil spill: recovery of rocky shore communities. In: Thayer, G. W. (ed.) Restoring the nation's marine environment. Maryland Sea Grant College, College Park, p. 583-631

Houghton, J. P., Fukuyama, A. K., Lees, D., Mearns, A. (1992). Impact of 'Exxon Valdez' oiling and shoreline treatments on intertidal communities - two years later. In: Proceedings of the seventh annual information transfer meeting. U.S. Department of the Interior, Minerals Management Service, Pacific OCS Region, Camarillo, CA, p. 197-211 
Hurlbert, S. H. (1984). Pseudoreplication and the design of ecological field experiments. Ecol. Monogr. 54: 187-211

Lees, D. C. (1992). What can southern California learn from the 'Exxon Valdez' oil spill experience? In: Grifman, P. M., Yoder, S. E. (eds.) Perspectives on the marine environment. Univ. of So. California Sea Grant Program, Los Angeles, p. 105-125

Lewis, J. R. (1964). The ecology of rocky shores. English University Press, London

Lubchenco, J. (1982). Effects of grazers and algal competitors on fucoid colonization in tide pools. J. Phycol. 18: $544-550$

Lubchenco, J. (1983). Littorina and Fucus: effects of herbivores, substratum heterogeneity, and plant escapes during succession. Ecology 64: 1116-1123

Mann, K. H., Clark, R. B. (1978). Long-term effects of oil spills on marine intertidal communities. J. Fish. Res. Bd Can. 35: $791-795$

Marshall, E. (1989). Valdez: the predicted oil spill. Science $244: 20-21$

McCook, L. J., Chapman, A. R. O. (1991). Community succession following massive ice-scour on an exposed rocky shore: effects of Fucus canopy algae and of mussels during late succession. J.exp. mar. Biol. Ecol. 154: 137-169

McCook, L. J., Chapman, A. R. O. (1992). Vegetative regeneration of Fucus rockweed canopy as a mechanism of secondary succession on an exposed rocky shore. Botanica mar. 35: 35-46

Michel, J. (1990). The 'Exxon Valdez' oil spill: status of the shoreline. Geotimes 35: 20-22

Michel, J. (1991). Prince William Sound, Alaska: the cleanup continues. Geotimes 36: 16-17

Mielke, J. E. (1990). Oil in the ocean: the short- and long-term impacts of a spill. Congressional Research Service, The Library of Congress, Washington, DC

National Research Council. (1985). Oil in the sea: inputs, fates, and effects. National Academy Press, Washington, DC

O'Brien, P. Y., Dixon, P. S. (1976). The effects of oils and oil components on algae: a review. Br. Phycol. J. 11. 115-142

Ricketts, E. F., Calvin, J., Hedgepeth, J. W., Phillips, D. W. (1985). Between Pacific tides, 5th edn. Stanford University Press, Stanford

This article was submitted to the editor
Schonbeck, M., Norton, T A. (1978). Factors controlling the upper limits of fucoid algae on the shore. J. exp. mar. Biol. Ecol. 31: 303-313

Sergy, G. A. (1985). The Baffin Island oil spill (BIOS) project: a summary. In: Proceedings of the 1985 oil spill conference. American Petroleum Institute, Washington, DC, p. $571-575$

Siva, J. L. (1979). Ecological impact of oil spill cleanup: are they significant? In: Proceedings of the 1979 oil spill conference. American Petroleum Institute, Washington, DC, p. 521-524

Sousa, W. P. (1984). Intertidal mosaics: patch size, propagule availability, and spatially variable patterns of succession. Ecology 65: 1918-1935

Southward, A. J., Southward, E. C. (1978). Recolonization of rocky shores in Cornwall after use of toxic dispersants to clean up the 'Torrey Canyon' spill. J. Fish. Res. Bd Can. 35: $682-705$

Stacey, B. M., Marcotte, B. M. (1987). Chronic effect of No. 2 fuel oil on population dynamics of harpacticoid copepods in experimental marine mesocosms. Mar. Ecol. Prog. Ser 40: $61-68$

Stone, R. (1992). Oil-cleanup method questioned. Science 257: $320-321$

Strand, J. A., Cullinan, V. I., Crecelius, E. A., Fortman, T. J., Citterman, R. J., Fleischmann, M. L. (1992). Fate of bunker C fuel oil in Washington coastal habitats following the December 1988 Nestucca oil spill. Northw. Sci. 66: 1-14

Straughan, D. (1983). Sandy beach communities exposed to natural oil seepage. In: Proceedings of the 1983 oil spill conference. American Petroleum Institute, Washington DC, p. $485-489$

Underwood, A. J., Jernakoff, P. (1984). The effects of tidal height, wave exposure, seasonality and rock-pools on grazing and the distribution of intertidal macroalgae in New South Wales. J. exp. mar. Biol. Ecol. 75: 71-96

Vadas, R. L., Wright, W. A., Miller, S. L. (1990). Recruitment of Ascophyllum nodosum: wave action as a source of mortality. Mar. Ecol. Prog. Ser. 61: 263-272

Wright, P. J., Reed, R. H. (1990). Effects of osmotic stress on gamete size, rhizoid initiation and germling growth in fucoid algae. Br. Phycol. J. 25: 149-155

Manuscript first received: June 14, 1993

Revised version accepted: January 5, 1994 